\title{
EXAMINATION OF DON-TOXIN CONTENT OF MILLING BYPRODUCT GENERATED AFTER COLOR SORTING
}

\author{
${ }^{1}$ Eleonóra Kecskésné-Nagy, ${ }^{2}$ Helga Tima, ${ }^{3}$ Péter Korzenszky, ${ }^{3}$ József Nagy \\ ${ }^{1}$ Neumann János University Faculty of Horticulture and Rural Development, Mészöly Gyula tér 1., 6000 Kecskemét, Hungary, \\ ${ }^{2}$ Szent István University Department of Microbiology and Biotechnology, Villányi út 29-43., 1118 Budapest, Hungary, \\ ${ }^{3}$ Szent István University Faculty of Mechanical Engineering, Páter Károly út 1., 2100 Gödöllö, Hungary, \\ e-mail: nagy.nori@kvk.uni-neumann.hu
}

\begin{abstract}
Thanks to the favorable impact of vintage effect occurring in recent years the Fusarium contamination of wheat and consequently a high DON-toxin concentration is often caused problem. The DON-toxin in terms of human and animal health is a serious food safety risk factor. Therefore, it is important that there are methods during the wheat milling process which reduces the level of toxin. We confirmed in our earlier examinations, that with the help of modern color sorting machine the DON-toxin content of wheat items is effectively can be reduced. The question is, during the process how parallel changes the mycotoxin content of by-products, which are used primarily as animal forage. The authors are presented an analysis of these relevant experimental data. The results show, that the toxin content of the byproduct is exceeds the starting wheat item's toxin content. However, the result of the regression analysis shows that no correlation in the toxin contents between the starting raw material, purified wheat and by-product. This should be considered to the users when they would like to utilize the by-product as ingredient of forage or feedstuff.
\end{abstract}

Keywords: DON-toxin, wheat, by-product, color sorting

\section{INTRODUCTION}

The production of safe products, that is the guarantee of food safety is primarily important in the entire system of food chain both during the production of foods and forages. It is important to assess the risk of the technology and to maintain it proficiently. This is supported by food safety laws and standards.

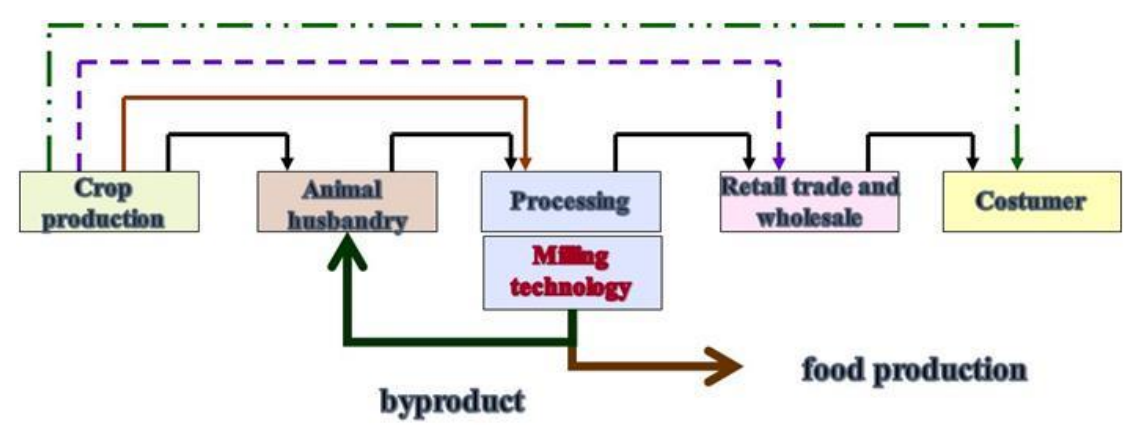

Figure 1. The return of milling by-products into the food chain

The goal of milling technology is direct food production. That is flour production from appropriate quality wheat which flour is basic material for pasta, bread and numerous essential foods. During the processing by-product is produced also, which primarily is used for animal forage. (Figure 1.)

This means, even if in an indirect way, these materials will get in touch with human body. That is the determination of the risks of by-product production and the development of treatment options is equally important as in the flour production. Producers particularly have to keep in mind this, when they perform developments or changes in the technological process. It is not enough just to concentrate on main 


\section{Analecta Technica Szegedinensia}

processes, but parallel the effect on by-product process must be analyzed also. Even in this case the requirements of legislation, and food safety regulation must be kept.

According to the above line of thought, there are two aspects of our research work when we investigate the reduction possibilities of DON-toxin content of milling wheat after harvesting. The primary goal is to investigate, whether usage of modern equipments in the production process has significant, and reliable effect on the reduction of mycotoxin content of wheat. Our experimental results proved the toxin level reliably can be decreased by application of adequate sorting and surface cleaner machines [13], [14]. But the question arises: This case how changes the toxin content of by-product, which primarily is used as forage. This is second aspect of research. We present the relevant data in this article. The topic is deliberately current issue, since in the last years several places intense Fusarium infection was experienced in the harvested wheat, which can cause high DON-toxin contamination.

Mycotoxins occur in the foods are secondary metabolic products produced by mould fungi. These have strong toxin effect, therefore they represent high risk in food safety respect [2], [11]. They can cause serious complications in human and animal bodies, illness which take shape shorter or longer period, and in many cases permanent damage [7], [10]. In cereals Fusarum ssp. is the most frequently occurring fungus. Compared with the most significant toxin producing fungi - like Aspergillus, Penicillium genera Fusarium species are on the first place, because they produce one-third of the mycotoxins [11].

Fusarium species are parasitic orgasms on many cultivated plants, but they cause the biggest damage on cereals [8]. The fungi infect cereals during the plant cultivation period in the field. Growing of fungi and formation of toxin may continue after harvesting also, if the cereals intended for food and the fodder industry are not handled properly [3].

The infection can cause significant economic damage in plant cultivation and animal husbandry equally. Getting into food chain the human health consequences may be considerable [4], [12]. Frequently occurring representative of fusariotoxins is the deoxinivalenol, or vomitoxin, more commonly known as DON-toxin. In reference [4] opinion this toxin occurs most frequently in wheat. Since this mycotoxin might be present both in cereals and cereal products it has great importance from food safety aspect.

The weather factors play a key role in appearance of toxin infection and in the development of toxin content of cereals [15]. The rainy, humid weather is favourable for fungi infection. However the effect of unfavourable ecological conditions can be decreased by application of preventive agrotechnical procedures [6]. According to the experiences the rainy weather results higher toxin level in the period of blooming and harvesting of wheat.

The size and the chracteristic of fusarium infection depends on which phenological phases was attacked the wheat by the fungi, that is the environmental conditions in which phenological phases are good for multiplication of fungi. This determines whether the seed-coat or the endosperm was effected by fungi infection. The color and the specific gravity of grain depends on the characteristic of infection. The difference of color and the specific weight determines the opportunity of sorting grains with higher toxin content, that is which applicable methods should be chosen to reduce toxin content of wheat item.

The experimental results of Reference [5] clearly proved the processes described in the preceding paragraph. Beyond that he demonstrated by analyses of infected wheat items there is no close correlation between the infection of outer and inner part of grain, that is formation of infection caused by different factors. All of this demonstrates: conventional cleaning, sorting methods cannot decrease reliably and efficiently the toxin concentration of grain items, that requires application of modern equipments.

\section{MATERIALS AND METHODS}

During our research work we investigated, whether DON-toxin contamination can be decreased in the milling process by application adequate and modern machinery. It is primarily important to guarantee the toxin content of end-product flour remain below the legal allowable level in all circumstances. Beyond the legal requirements it is important also to keep the toxin level of basic foods as low as possible, reducing the intake of harmful substances into human body by foods.

DOI: 10.14232/analecta.2019.2.38-46 


\section{Analecta Technica Szegedinensia}

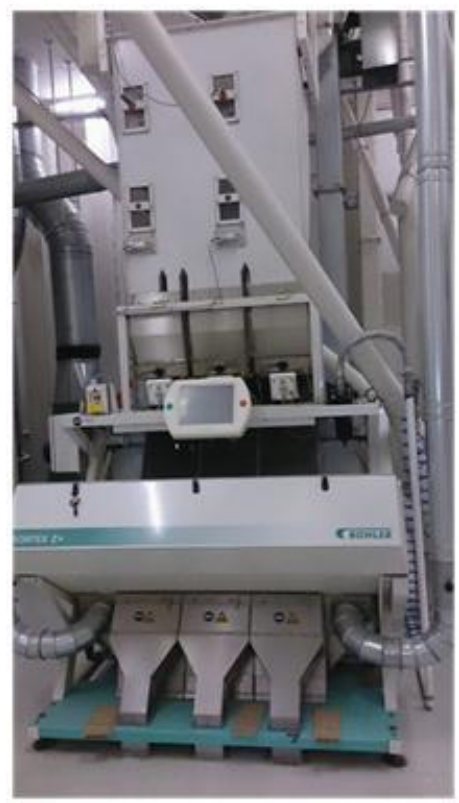

Figure 2. Sortex Z+ Optical Sorter

Primary goal of our research work was to investigate whether achievable positive result by color sorting of grain items. To this we completed cleaning with Sortex Z+ color sorting machine (Figure 2.), then we measured the DON-toxin content of milling wheat samples before and after cleaning. But after cleaning of the milling wheat by-product is produced also, which is used as forage. (Figure 3.) That is this by-product return into the food chain too. (Figure 1.) It is shown from the process, that toxin content of milling wheat can be decreased by color sorting, but the mycotoxin content of by-product should be increased parallel. The question is: Is it possible to draw a conclusion about toxin concentration of by-product - used as forage - from the toxin content of starting raw material or purified milling wheat? That is the results of measures have done during the processing are suitable to decide whether the by-product is usable for forage production? To get answer we investigated the toxin concentration of wheat samples taken from three fraction and the results were evaluated statistically. Detailed description is in the chapter „Materials and methods".

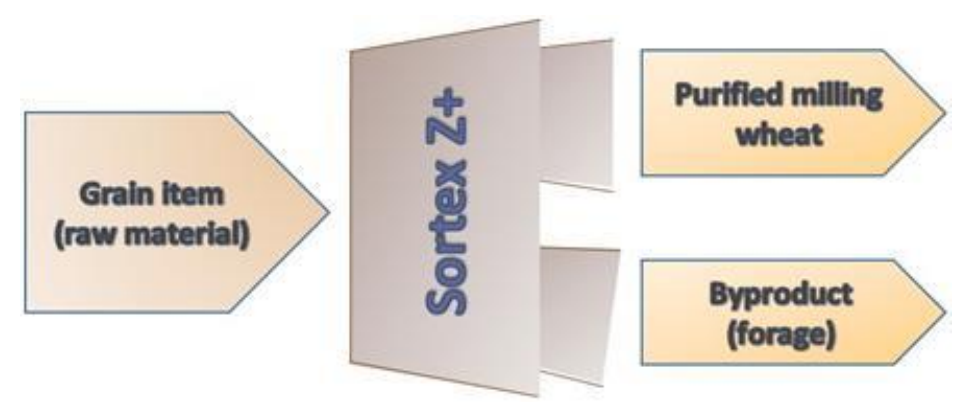

Figure 3. Operational scheme Sortex $Z+$ color sorter 


\section{Analecta Technica Szegedinensia}

The place of research was a mill, which has one of the most up-to-date technology in Hungary. We consider of importance to put the investigation into real production environments where the food safety technology and its operation can be studied directly. This type of investigation is not possible with model experiments. When we choose the place we looked for a mill where the experiments are achievable in controlled circumstances, complete mechanism of production process and its environment is transparent, trackable and measurable. Besides these the conditions and the experimental settings should be changeable and repeatable.

The basic material of experiment was durum wheat (Triticum durum). This species was chosen on the basis of the cultivation experience described in the literature. It was observed during the cultivation, that durum wheat is more sensitive to fusarium infection than other wheat species [1].

The characteristic of infection is widely influenced by vintage effect, as it was previously mentioned. Therefore the subject of investigation was the analysis of wheat items harvested in different years. In this article we summarized the evaluation results of samples of wheat items harvested in 2013 and 2014. The sampling system was elaborated according to the technological phases because of nonstop operation. The goal is to follow up the change of toxin content of wheat items during the production process. We formed three sampling place at the Sortex color sorting machine. First sample was taken directly before sorting. This indicated the initial toxin content of raw material. During the evaluation it was called 1. fraction. After cleaning there were two fractions. 2. fraction was the purified milling wheat, from which the flour is milled at the end of technological process. 3. fraction is the selected by-product which can be used as basic material for forage (Figure 3.). DON-toxin content of each fraction was measured and analyzed by statistical methods. Toxin concentration was determined AgraQuant Deoxinyvalenol test kit, which operates with ELISA method and distributed by Romer Labs.

\section{RESULTS AND DISCUSSION}

So far the results clearly revealed the DON-toxin content of wheat items reducible by application of Sortex $\mathrm{Z}+$ color sorting machine. The relevant analyses are described in detail in our previously published articles. This time we are looking for answer, whether there is correlation between toxin content of 3 . fraction and toxin content of starting raw material (1. fraction) or cleaned wheat (2. fraction).

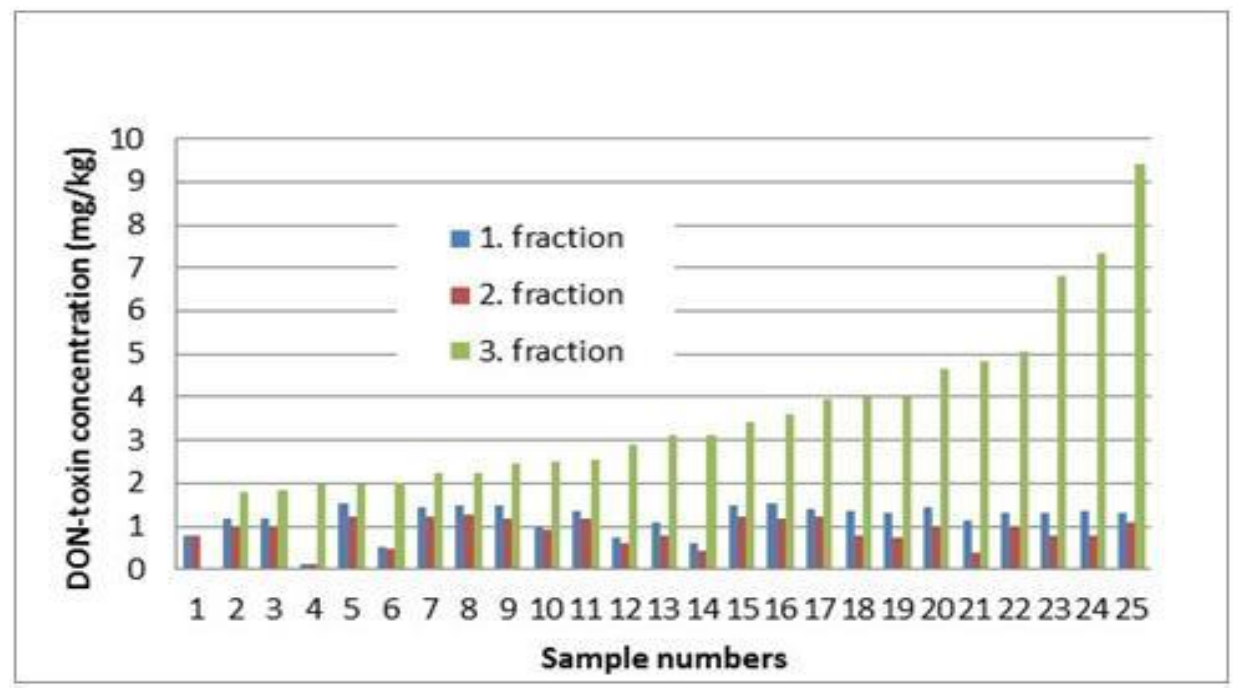

Figure 4. The DON-toxin content of generated fractions during the color sorting (2013.vintage) 


\section{Analecta Technica Szegedinensia}

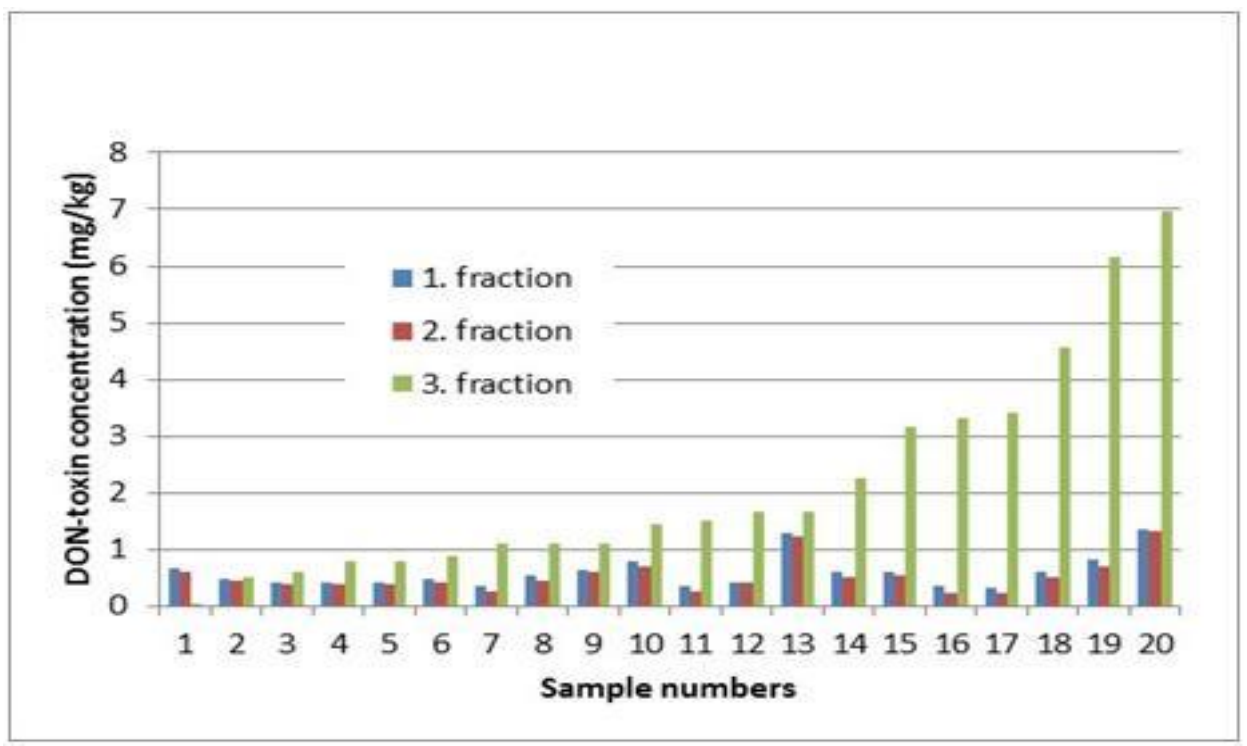

Figure 5. The DON-toxin content of generated fractions during the color sorting (2004. vintage)

Figure 4. and Figure 5. clearly show toxin content measured in 3. fraction is always higher than in the other two fractions.

To get answer to question raised in the first part of this chapter we arranged the samples ascending order according to DON-toxin content of 3. fraction in Figure 4. and 5. It is simply illustrated, if concentration of particular fractions has visible correlation with each other. The answer at first sight unambiguous „not”. Let pick up a data pair from the samples harvested in 2013 (Figure 4.) and a data pair from the samples harvested in 2014. (Figure 5.) and compare them. The results of comparison of samples 5. and 25. in the Figure 4. and the toxin content of samples 17. and 20. in the Figure 5. Our previous statement has been verified. There is no correlation between toxin content of three fractions neither in 2013 nor in 2014 harvested wheat items.

We used biostatistical methods to prove or reject our argumentation beyond any shadow of doubt. We completed detailed analysis by regression analysis. The correlation study can answer that question, if we can conclude the toxin content of by-product from initial DON-toxin concentration of wheat item or from DON-toxin content of cleaned wheat.

For the sake of filling the legal requirements we have to know the toxin contamination of starting raw material in order not to mill those wheat items which exceed the limit value. The simplest solution would be therefore to find statistical correlation between toxin concentration of starting raw material and the toxin concentration of by-product which can help to determine the contamination of by-product and to decide its further utilization. Thus first we did regression analysis referring to both vintage (Figure 6-7.).

According to Figure 6. (2013. vintage) the starting wheat item (fraction 1.) has $9 \%$ effect on DON-toxin concentration of by-product (fraction 3.), nevertheless $91 \%$ owing to the random effects. The Figure 7. shows, the initial toxin content of wheat had $24 \%$ effect on toxin contamination of by-product. It can be said in both cases, there is no linear correlation between data pairs, so cannot be drawn conclusion to the toxin effect of by-product. 


\section{Analecta Technica Szegedinensia}

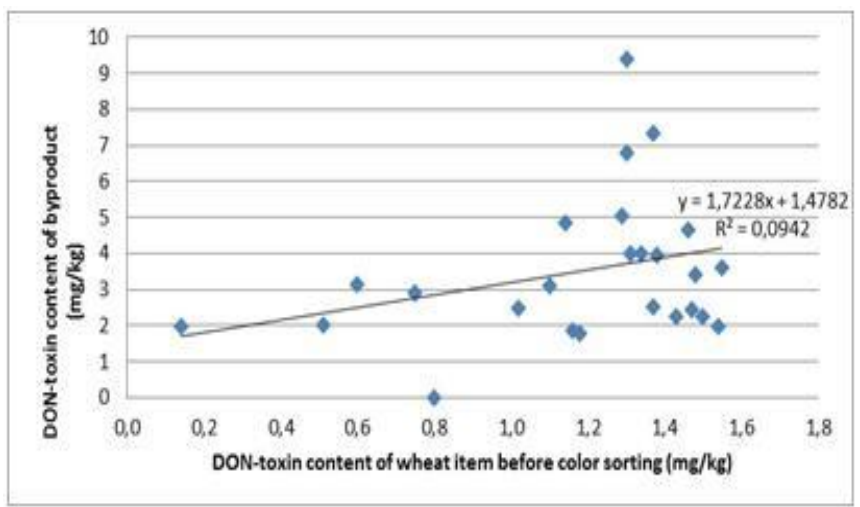

Figure 6. Correlation examination of the DON-toxin content between the wheat item before color selection (1. fraction) and milling by-product (3. fraction) (2013. vintage)

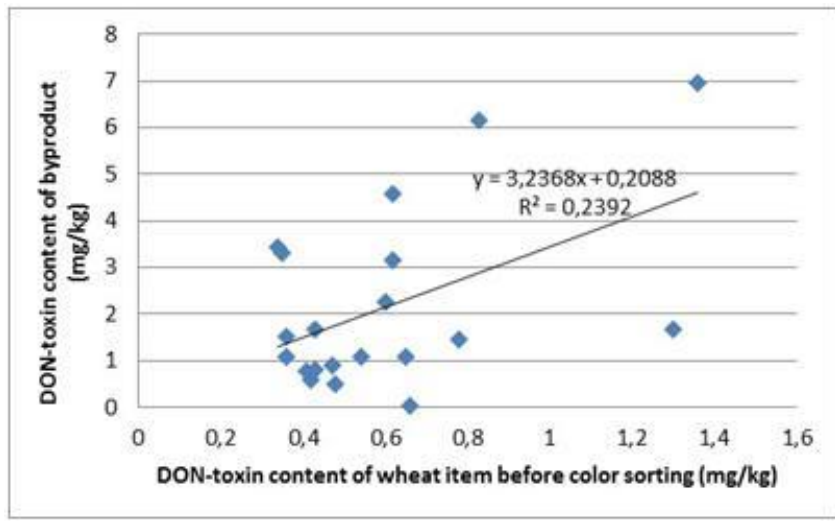

Figure 7. Correlation examination of the DON-toxin content between the wheat item before color selection (1. fraction) and milling by-product (3. fraction) (2014. vintage)

We investigated the correlation between 2. fraction (wheat after color sorting) and 3. fraction also. (Figure 8-9.).

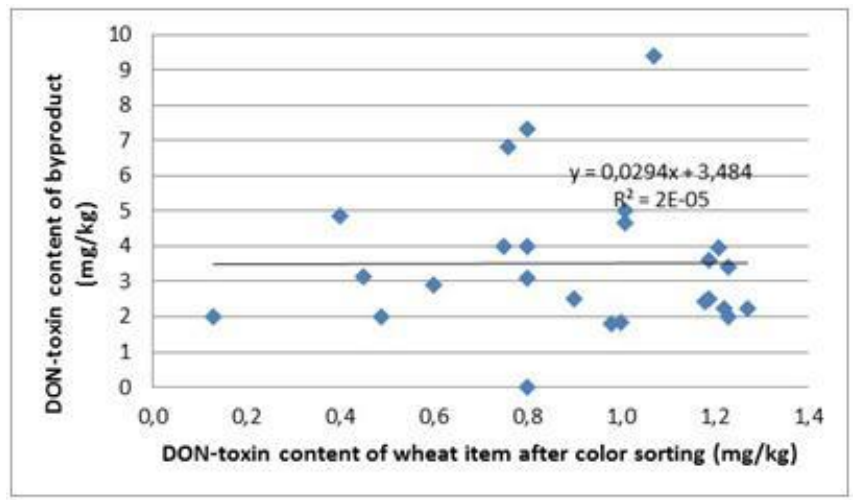

Figure 8. Correlation examination of the DON-toxin content between the wheat item after color selection (2. fraction) and milling by-product (3. fraction) (2013. vintage) 


\section{Analecta Technica Szegedinensia}

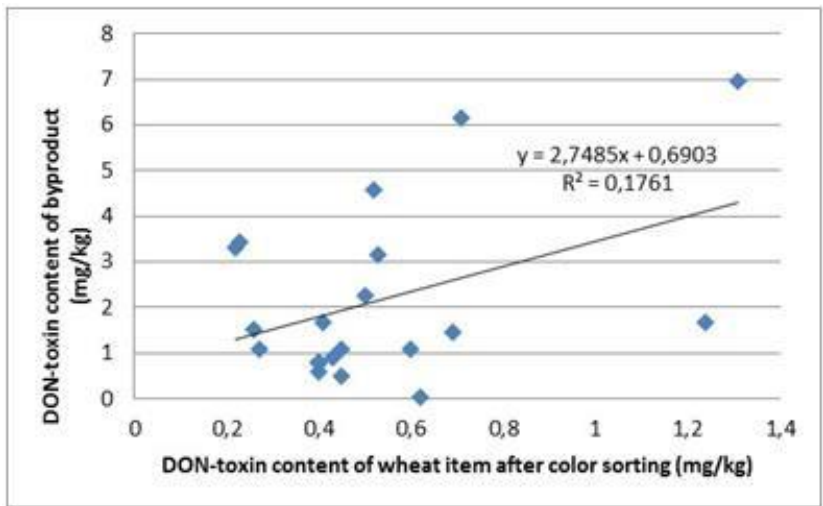

Figure 9. Correlation examination of the DON-toxin content between the wheat item after color selection (1. fraction) and milling by-product (3. fraction) (2014. vintage)

The result is similar to correlation examination of first and third fraction. Neither this case we found correlation between toxin concentration of sample pairs. We should highlight data of Figure 8., which display there is not at all correlation between toxin concentration of cleaned wheat and the toxin content of by-product. Thus these data will not give standing-point about quantity of harmful materials accumulated in the by-product.

It seems logical the rate of toxin reduction of 1 . fraction should be the most effective factor on by-product. Although it is not simple to determine this in the production practice. To the determination of efficiency and respectively to make correlation analysis, we have to create a difference sample from data of 1 . and 2 . fraction. So we have to measure parallel the toxin content of 1 . and 2. fraction also. The elements of difference sample are formed from the difference of data pairs of 1. and 2. fraction. The regression analysis also shows (Figure 10.-11.) there is no linear correlation between harmful materials of difference sample and by-product. Although the regression coefficient is higher than the results of previous correlation analysis were, but this does not mean close, function-like connection between two variables. From this we can draw the conclusion: DON-toxin content of by-product not only depends on efficiency of color sorting, but also other factors have role.

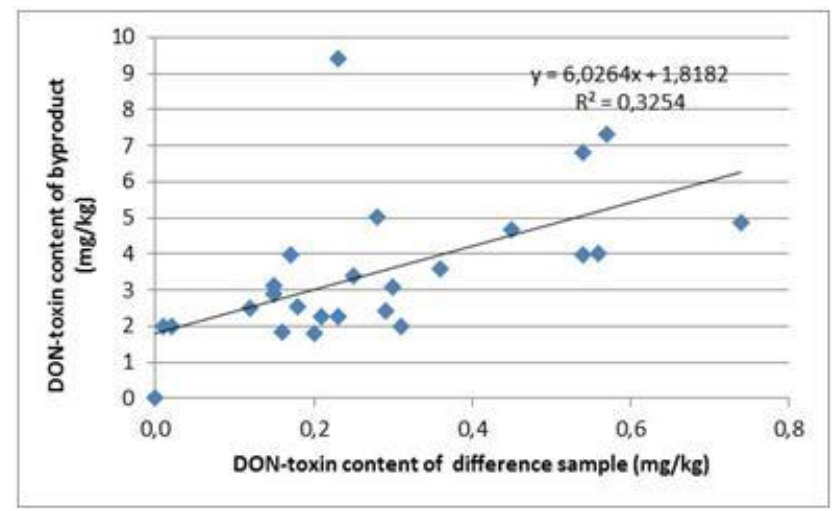

Figure 10. Correlation examination of the DON-toxin content between the difference sample (substraction of 1. and 2. fraction) and the by-product (3. fraction) (2013. vintage) 


\section{Analecta Technica Szegedinensia}

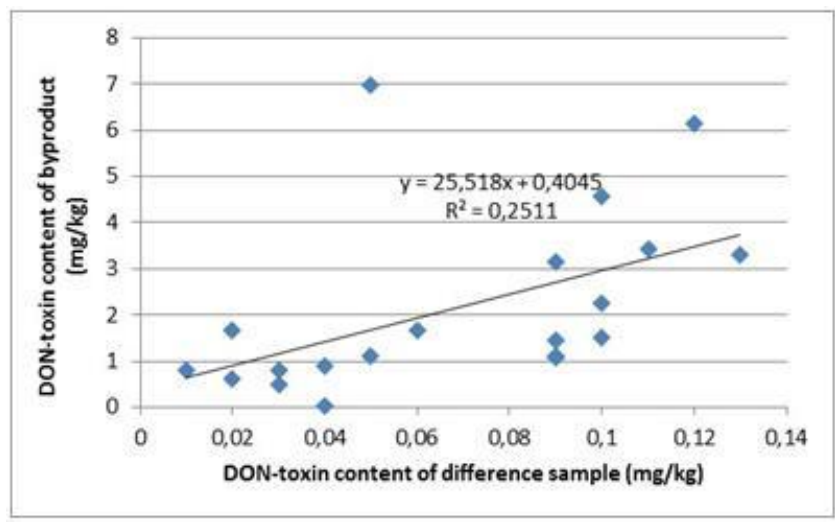

Figure 11. Correlation examination of the DON-toxin content between the difference sample (substraction of 1. and 2. fraction) and the by-product (3. fraction) (2014. vintage)

\section{CONCLUSIONS}

From the results above we can come to the conclusion the color sorting of wheat intended for milling does not show close correlation neither with starting wheat nor with purified wheat toxin content (Figures 6-11.) That means it might occur we get by-product with high level harmful material after cleaning of wheat, which has low rate DON, and vice versa (Figures 4-5.). People who works in the milling industry should know this fact, because in many instances the cleaning by-product is sold as forage.

The color sorting that is the efficiency of cleaning does not show unambiguous correlation referring the toxin content of by-product. The reason of this can be explained by several factors. On the one hand the color sorting can select a high percentage of grains, which were infected in the early phase of blooming. A part of grains, which were infected in late phase of blooming do not show discoloration and they pass on process, because they are not selected. The rate of grains in a wheat item with different contamination character depends on vintage effect and agricultural technology applied during cultivation.

Toxin content of by-product is influenced by what kind of other components are selected and in which quantity by the color sorting machine. This determines the quantity of by-product and the rate of toxin contaminated grains within it. Besides the efficiency of preselection the vintage effect has role in determination of by-product. The vintage affects what kind of other infection attack the wheat, which might cause discolouration also. But the content of by-product depends on glassiness of grain, effectiveness of pre-cleaning and there are other deviations which besides the fusarium infected grains cause the selection from the milling wheat during color sorting.

Summing up we can say, if the mills intend to utilize the by-product as forage, they have to elaborate a test system which determine its DON-toxin content. The food safety requirements thus can be ensured under all circumstances, as well as the items with higher level toxin content than allowable level will not get into food chain.

There is a recommendation in the EU about the DON-toxin of forages. In the case of cereals and cereal products the recommended maximum limit value of toxin content by the EU is $8 \mathrm{mg} / \mathrm{kg}(2006 / 576 / \mathrm{EC}$, [9]. In 2013. and 2014. vintage - which were not outstanding years from the point of fusarium infection of wheat - only one sample exceeded this limit. Thus if there is not possible to build up test system, the proper mixing rate is a way for the forage usage. 


\section{Analecta Technica Szegedinensia}

\section{REFERENCES}

[1] SZUNICS, L., VIDA, GY., VEISZ, O., LÁNG, L., BEDŐ Z. (2002): A Maxi és a Makaróni. Új őszi típusú, jó minőségű durum búza fajták. Martonvásár, az MTA Mezőgazdasági Kutató Intézetének közleményei. XIV. (2) 9-11.

[2] GAlVANO, F., GAlOFARO, V., GALVANO G. (2005): Mycotoxins in the human food chain. In: Diaz D. (eds.): The Mycotoxin Blue Book. Nottingham Press, 187-224.

[3] VÁRADI, M. (2005): Az élelmiszerbiztonság és -minőség kihívásai az élelmiszeranalitikában. Magyar Kémiai Folyóirat, 111 (3) 118-123.

[4] MESTERHÁZY, Á. (2007): Mikotoxinok a gabonatermesztésben: az élelmiszerbiztonsági kihívás. Élelmiszervizsgálati közlemények,. LIII. kötet. (53 különszám). 38-48.

[5] VERES E., BORBÉLY M. (2007): Az őszi búza felhasználhatósága a vizuális és mikrobiológiai Fusarium fertőzöttség-, valamint a toxin vizsgálatok alapján. Agrártudományi közlemények, (12), 2634. o.

[6] PRINCZINGER, G. (2009): Búza, fuzáriumok, toxinok. MezőHír, 8(8):14-18.

[7] RAFAI, P., KOVÁCS, M. (2009): A takarmányok mikotoxin szennyezettségének igazságügyi állatorvostani vonatkozásai. Állattenyésztés és Takarmányozás, 58. (5), 413-424.

[8] AMBRUS, Á., SZEITZNÉ SZ, M. (2010): Gabona alapú termékek mikotoxin szennyezettségének élelmiszerbiztonsági értékelése. Élelmiszer, Tudomány, Technológia LXIV. (1) 10-14.

[9] BÚZA, L., SCHILL, J. (2010): A mikotoxinok vizsgálati módszerei, eredményei, előfordulásuk a hazai takarmányokban. In: Kovács M. (szerk.): Aktualitások a mikotoxin kutatásban. Agroinform Kiadó. Budapest, 14-19.

[10]KOVÁCS, M. (2010): A mikotoxinok humán-egészségügyi vonatkozásai. In: Kovács M. (szerk.): Aktualitások a mikotoxin kutatásban. Agroinform Kiadó. Budapest, 86-102.

[11]DEÁK, T. (2011) Élelmiszer-mikrobiológia. Mezőgazdasági Kiadó. 382. ISBN 9789632866345

[12] SZABÓ-HEVÉR, Á. (2013): A kalászfuzárium rezisztencia molekuláris hátterének vizsgálata frontana eredetü térképező búzapopulációkban, SZIE, Doktori értekezés. 141.

[13] KECSKÉSNÉ NAGY, E., SEMBERY, P. (2014): Egy malomipari feldolgozási folyamat műszaki feltételeinek a vizsgálata élelmiszerbiztonsági szempontból. Gradus 1:(2) 44-50.

[14]NAGY KECSKÉSNÉ, E., SEMBERY, P. (2015): Color sorting of bread-making wheat and change of toxin content. Annals of Faculty Engineering Hunedoara / International Journal of Engineering 13:(1) 171-174.

[15]COMMISSION RECOMMENDATION of 17 August 2006 on the prevention and reduction of Fusarium toxins in cereals and cereal products (Celex number: 32006H0583) 